\title{
LA PLEGARIA COMO MACRODISCURSO DE LOORES DE NUESTRA SEÑORA DE GONZALO DE BERCEO
}

\section{THE PRAYER AS THE MACRO-DISCOURSE OF LOORES DE NUESTRA SEÑORA BY GONZALO DE BERCEO}

\author{
María Belén Navarro \\ Universidad Católica Argentina
}

Resumen: El presente trabajo se propone definir y clasificar con precisión el tipo textual, la macroestructura y superestructura específica del poema Loores de Nuestra Señora de Gonzalo de Berceo mediante un análisis integral del texto en el marco de una pragmática textual, que tenga en cuenta los macroactos y microactos de habla para delimitar sus intenciones y finalidades. La hipótesis basal postulada radica en su clasificación como una plegaria compleja de alabanza y petición, determinada por el macrotexto, en la cual un locutor humano se dirige a un alocutario santo, María, coprotagonista ensalzada de la historia de la salvación según los cánones propios de la devoción mariana de hiperdulía de la época. Tal alabanza requiere de un microdiscurso subordinado pragmáticamente a la macroestructura laudatoria: la narratioargumentatio, en otras palabras, la narración de los hechos salvíficos funcionan como alegato a favor de la loa debida a la Virgen y fundamento de la petición final.

Palabras clave: Loores de Nuestra Señora - plegaria - alabanza

\begin{abstract}
This paper aims to define the textual type, the macrostructure and the specific superstructure of the poem Loores de Nuestra Señora by Gonzalo de Berceo. The methodology employed is textual analysis, which also involves the classification of the macroacts and microacts of speech in the context of textual pragmatics to determine the intentions and purposes of the poem. The main hypothesis is that the poem is a complex prayer of worship and petition, established on the macrotext, in which a human speaker addresses a holy hearer, Mary, a central character of the history of salvation according to the standards of the Marian devotion of that time. Such praise requires a microtext pragmatically embedded to the laudatory macrostructure: the narratioargumentatio. The narration of the salvific facts works as an argument in favor of the worship owned to the Virgin and the basis of the final request.
\end{abstract}

Key words: Loores de Nuestra Señora prayer - worship

Recebido em: 25/06/2016

Aprovado em: 01/12/2016 
Loores de Nuestra Señora una obra menor dentro de la clasificación temática de poemas marianos del primer poeta de la literatura en castellano cuyo nombre se conoce, Gonzalo de Berceo. Su análisis específico ha tardado en desarrollarse y, en general, se ha focalizado en rasgos aislados y puntuales, por lo cual puede afirmarse que existe un vacío en la actualidad en lo que compete al análisis integral del texto, que abarque de una manera sistemática y coherente tanto su configuración textual como su finalidad e interpretación. El presente trabajo se propone definir con precisión y clasificar el tipo textual, la macroestructura y superestructura específica del poema. En consecuencia, será preciso efectuar un análisis integral del texto, particularmente de sus componentes estructurales y retóricos, para aproximarse a una interpretación del sentido global de la obra.

La hipótesis basal postulada radica en su clasificación como una plegaria compleja de alabanza y petición, determinada por el macrotexto, en la cual un locutor humano se dirige a un alocutario santo, María, coprotagonista ensalzada de la historia de la salvación según los cánones propios de la devoción mariana de hiperdulía de la época. Tal alabanza requiere de un microdiscurso subordinado pragmáticamente a la macroestructura laudatoria: la narratio-argumentatio, en otras palabras, la narración de los hechos salvíficos funcionan como alegato a favor de la loa debida a la Virgen y fundamento de la petición final.

\section{Loores de Nuestra Señora como discurso religioso}

El carácter religioso de la producción poética de Gonzalo de Berceo suele ser un dato evidente y ampliamente afirmado por la crítica. Dentro del conjunto, Loores de Nuestra Señora suele ser clasificado específicamente como un poema religioso dedicado a la Virgen María. Es preciso delimitar la extensión de esta definición y categorización dentro de los "discursos religiosos" como punto de partida y anclaje de esta investigación sobre la constitución textual de esta obra de Gonzalo de Berceo, con el objetivo de dilucidar cuáles son las notas textuales y pragmáticas que lo definen.

Desde una perspectiva lingüística, se entiende por texto una estructura compleja compuesta de secuencias, que son su unidad constituyente y modélica. Estas presentan

$$
121
$$


una organización interna propia, que puede descomponerse en partes, y se combinan de forma jerárquica. Por ende, para determinar el tipo de texto, es imprescindible identificar la disposición de estas secuencias y sus combinaciones, la dominancia de una sobre otras (en caso de ser heterogéneas) y la clase de relación entablada entre ellas, ya sea de concatenación, de alternancia o de dependencia. Loores de Nuestra Señora es un poema complejo desde este enfoque, dado que posee una heterogeneidad interna llamativa, razón por la cual ha sido calificada como "una mezcla de relatos bíblicos acabados con un elogio a la Virgen"1 o "una recapitulación de las alusiones a la Virgen en la Ley Vieja hasta la vida de Jesús"2. En consecuencia, es preciso reconocer la disposición de estos componentes aparentemente tan inconexos. Es posible identificar una secuencia dominante (aquella que se manifiesta con una presencia mayor en el conjunto del texto) en cuyo marco aparecen secuencias secundarias incrustadas (llamadas también microtextos insertos en segundo grado), tornando a la primera envolvente ${ }^{3}$. La "presencia mayor" no se determina por cuestiones cuantitativas, sino por ser el molde discursivo de un texto considerado íntegramente, en otras palabras, el macrodiscurso.

En lo que concierne al nivel macrotextual, Loores de Nuestra Señora es un poema religioso, determinado como "todo aquel que postule la existencia real y operante de una dimensión trascendente o santa a través de su explícita textualización en relación con el locutor, el referente o el alocutario del discurso"4. Esta definición propone un desplazamiento del plano de análisis de lo semántico (en otras palabras, la relación entre el discurso y sus referentes propios) a lo pragmático (la relación que a través del discurso entablan sus usuarios, principalmente el emisor y el receptor). Por ende, se requiere la delimitación del rol desempeñado por el sujeto divino o santo dentro del circuito comunicativo del acto de habla ${ }^{5}$ que implica todo discurso religioso. González propone

\footnotetext{
${ }^{1}$ Alborg, Juan Luis. El mester de clerecía. In: Historia de la literatura española. Madrid: Gredos, 19671980, v. 1: Edad Media y Renacimiento, p. 110-147, especialmente p. 129.

2 YNDURÁin, Domingo. Algunas notas sobre Gonzalo de Berceo y su obra, Berceo, n. 90, 1976, p. 3-67, especialmente p. 39.

3 Adam apud CAlsamiglia Blancafort, Helena; Tusón Valls, Amparo. Las cosas del decir. Manual de análisis del discurso. Barcelona: Ariel, 1999, p. 253-257.

${ }^{4}$ GonzÁleZ, Javier Roberto. Plegaria y profecía. Formas del discurso religioso en Gonzalo de Berceo. Buenos Aires: Circeto, 2008, p. 59.

${ }^{5}$ La teoría de los actos de habla según John L. Austin distingue, en cada enunciado lingüístico, tres actos o modos de "hacer algo" mediante ese enunciado: un acto locutivo, que consiste en el significado literal generado por una cadena de sonidos (acto fonético) organizados en palabras construidas según determinada morfología (acto fático) y portadoras de un sentido y una referencia determinadas (acto rético); al realizar
} 
una clasificación en cuatro tipos posibles de macrodiscursos religiosos según el rol desempeñado por la textualización de lo trascendente-santo: el discurso profético ${ }^{6}$, el discurso-plegaria ${ }^{7}$, el discurso narrativo y el discurso expositivo-instruccional ${ }^{8}$. A la luz de esta concepción teórica, se puede afirmar que Loores de Nuestra Señora se configura como un discurso religioso en cuanto textualiza la dimensión trascendente-santa mediante diferentes roles a lo largo de todo el poema y concretamente como plegaria en su macrotexto.

\section{Loores como plegaria: el acto de habla fundante}

La dominancia de las secuencias no se establece por una cuestión cuantitativa de materia verbal, sino cualitativa, relacionada con el molde textual y la relación instaurada entre los microtextos. Por lo tanto, una de las claves para poder delimitar la finalidad última de Loores de Nuestra Señora es la determinación de su género, dado que todo texto es una unidad semántica y pragmática de sentido, intencional y de interacción; es un acto comunicativo ${ }^{9}$. En consecuencia, subyace en él un acto de habla fundante, que da origen

este acto locutivo, el hablante efectúa asimismo un segundo acto, llamado ilocutivo, que asigna un valor intencional (prometer, ordenar, pedir, advertir, felicitar, sugerir, etcétera) a las palabras emitidas; en tercero y último lugar, existe un acto perlocutivo, que son las consecuencias o efectos que el enunciado produce sobre los pensamientos, sentimientos o acciones de la audiencia. En otras palabras, el acto ilocutivo se realiza al decir algo y el perlocutivo se realiza porque se ha dicho algo. El acto locutivo posee significado, el ilocutivo posee fuerza y el perlocutivo efectos (Austin, John. Cómo hacer cosas con palabras. Palabras y acciones. Barcelona: Paidós, 1990, p.138-168; CASALMIGLIA, op.cit., p. 186-187).

${ }^{6}$ El discurso profético es todo aquel en el cual la dimensión trascendente-santa se encuentra textualizada como locutor, en primera persona (mediatizada por la voz vicaria de un santo profeta), y especificado como trascendente-descendente, en tanto un emisor divino o celestial desciende hacia un receptor humano o terreno: "Dios me dice a mí, hombre" (GONZÁLEZ, op. cit., p. 65).

7 El discurso-plegaria es aquel donde lo trascendente-santo se textualiza como alocutario, en segunda persona; lo trascedente se especifica como trascendente-ascendente, en tanto un emisor humano o terreno asciende hacia un receptor divino o celestial: "Yo, hombre, digo a Dios/los ángeles/los santos" (GoNZÁLEZ, op. cit., p. 65).

${ }^{8}$ En cuanto a la textualización trascendente-santa como referente, existen dos posibilidades: como actante de una trama desenvuelta en el tiempo (la narración) o como acción descripta y prescripta, en tanto causa $\mathrm{u}$ origen legitimador de la norma moral o litúrgica o como sentido último de la experiencia humana (GONZÁlEZ, op. cit., p. 63). En consecuencia, es conveniente distinguir entre el discurso narrativo, que textualiza la dimensión trascendente como referente-actante en tercera persona y especificado como trascendente-horizontal en un plano de inmanencia hombre-hombre: "Yo digo a otros hombres acerca de lo que Dios o los santos hacen", y el discurso expositivo-instruccional, el cual textualiza lo trascendente como referente-acción, también en tercera persona y especificado como trascendente-horizontal: "Yo digo a otros hombres acerca de qué y cómo son y se hacen las cosas de Dios" (GONZÁlEZ, op. cit., p. 65).

${ }^{9}$ CAlsamiglia, op. cit., p. 209. 
no sólo al texto concreto, sino también a cada género discursivo ${ }^{10}$, capaz de definirlo en su intención fundamental, atendiendo especialmente a la fuerza ilocutiva del enunciado, cuya interpretación está dispuesta por el contexto de enunciación. Tal acto de habla puede ser inferido a partir de la determinación de la superestructura del texto, definida como "las estructuras globales que caracterizan el tipo de un texto"11.

En lo que concierne a la superestructura de la plegaria - género propuesto para el macrotexto de Loores de Nuestra Señora -, González ${ }^{12}$, luego de un análisis detenido y minucioso de las realizaciones microtextuales de los distintos tipos de este discurso religioso en las obras de Gonzalo de Berceo, ha postulado una superestructura común, teniendo en cuenta las partes tradicionales de la dispositio retórica, que permite inferir el acto de habla único de la plegaria:

\section{Tú / A ti}

(eres / agradezco / en vista de / aunque $\mathrm{X}$ ) (haz Y)

(porque Z) invocatio

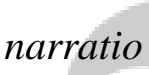

petitio

argumentatio

La invocación es la única parte que nunca falta en ninguna clase de plegaria y la que más se enfatiza en todas ellas, como apelación directa o indirecta que se dirige a la segunda persona del alocutario. En consecuencia, puede concluirse que el acto de habla básico en el que la plegaria encuentra su origen como género discursivo es un enunciado tú-valorativo, esto es, enunciados cuya función pragmática es la de emitir juicios sobre el alocutario $^{13}$, según se desprende de la apelación latréutica en que consiste la invocatio, que postula indirectamente un reconocimiento de la superioridad y el poder de la persona trascendente invocada. Por ende, el núcleo principal de la plegaria es la

\footnotetext{
${ }^{10}$ Todorov, Tzvetan. El origen de los géneros. In: Los géneros del discurso. Caracas, Monte Ávila, 1996, p. 47-64. Especialmente p. 51.

${ }^{11}$ Es necesario distinguir los conceptos de macroestructura y superestructura según la gramática textual de Teun VAN DIJK: "Denominaremos superestructuras a las estructuras globales que caracterizan el tipo de un texto. Por lo tanto, una estructura narrativa es una superestructura, independientemente del contenido (es decir, de la macroestructura) de la narración, aun cuando [...] las superestructuras imponen ciertas limitaciones al contenido de un texto. Para decirlo metafóricamente: una superestructura es un tipo de forma del texto, cuyo objeto, el tema, es decir: la macroestructura, es el contenido de un texto [...] Es decir que la superestructura es una especie de esquema al que el texto se adapta" (VAN DiJK, Teun. La ciencia del texto. Barcelona: Paidós, 1992, p. 142-143).

12 GONZÁleZ, op. cit., p. 123-124.

13 Stati, apud GONZÁLEZ, op. cit., p. 105.
} 
adoración/alabanza. A partir de este acto de habla básico fundante, cada plegaria posee una función específica según la cual puede ser subclasificada: lautréuticas o de adoración -reservada a Dios únicamente, y que encuentra su análogo para los santos en la plegaria de alabanza-; de acción de gracias o eucarísticas, de petición o impetratorias y de arrepentimiento y confesión de pecados o propiciatorias $^{14}$.

De esta manera, dada la categorización de la secuencia dominante de Loores de Nuestra Señora como plegaria, ya que la textualización de lo trascendente-santo se realiza como alocutario ${ }^{15}$, proponemos que se trata de un discurso religioso con una función básicamente laudatoria. La secuencia secundaria de carácter narrativo (estrofas 4-194), dedicada a referir la historia de la caída y la redención del hombre según el plan providencial de Dios, pragmáticamente se halla subordinada como una narratioargumentatio, según lo explica González:

a la manera de un acto de habla indirecto, esto es, a partir de su significado locutivo en cuanto enunciado asertivo-narrativo que refiere los grandes hechos salvíficos coprotagonizados por María junto a Cristo, cobra en realidad una fuerza ilocutiva de argumentación o prueba a favor de la alabanza debida a la Virgen, alabanza que radica textualmente en las secciones inicial y final del poema. ${ }^{16}$

Por lo tanto, el contenido doctrinal-catequístico que determinaba para Menéndez Peláez ${ }^{17}$ la clasificación de los LNS como didáctica doctrinal constituye un microtexto inserto, que expresa una microestructura, dentro de una macroestructura global indicada por el macrotexto, compuesto por la primera y última sección del poema (estrofas 1-3; $195-233)^{18}$.

${ }^{14}$ GONZÁleZ, op. cit., p. 26.

${ }^{15}$ Se emplea el término "alocutario", propio de la pragmática del discurso y de la teoría del diálogo, para discernir entre aquel a quien explícitamente se habla, designándolo mediante marcas discursivas inequívocas como interlocutor y aquel para quien se habla, esto es, aquel que aun sin ser designado como interlocutor se espera que reciba en última instancia nuestro mensaje -el destinatario- (Stati apud GONZÁLEZ, op. cit., p. 61). Dentro del marco del cristianismo católico, es evidente que el destinatario último de toda plegaria es Dios, pero es también posible, conveniente y lícita la plegaria de intercesión, esto es, "aquella plegaria que toma como alocutario directo de la apelación a un santo en el cielo, a un ángel o a un ánima del Purgatorio, para que éstos intercedan ante Dios por nuestros pedidos y lleven hasta Él nuestro arrepentimiento, nuestras gracias o nuestra alabanza" (GONZÁLEZ, op. cit., p. 27)

${ }^{16}$ GONZÁlEZ, op. cit., p. 67.

17 Ver MenÉndeZ PelÁEZ, Jesús. La tradición mariológica en Berceo. In: Actas de las Terceras Jornadas de Estudios Berceanos. Logroño: Instituto de Estudios Riojanos, 1981, p. 113-127. Especialmente p. 114115. El autor inscribe a Loores en la clasificación de obras referidas a una teología dogmática, dado que le asigna la finalidad de exponer la función de María en la economía de la salvación.

${ }^{18}$ En este sentido, también resulta errónea la estructuración cerrada y circular en tres partes propuesta para LNS por Isabel URÍA MAQUA. Ver: Panorama crítico del mester de clerecía. Madrid, Castalia, 2000, p. 


\section{Análisis formal y retórico del macrotexto de Loores de Nuestra Señora}

En función de poder fundamentar esta hipótesis, es necesario centrar el análisis en el macrotexto de Loores de Nuestra Señora para justificar el reconocimiento y la división de las secuencias dominantes y secundarias, observar las notas esenciales que la tornan plegaria y lograr delimitar su superestructura. Este estudio permitirá definir con mayor precisión la clase de plegaria a la cual pertenece y los actos de habla secundarios que pueden derivarse de la alabanza fundante. Se analizarán ambas secciones -exordio y conclusión- por separado a efectos expositivos, para poder determinar ciertas características específicas de cada una, pero sin olvidar su carácter unitario.

\section{A. Análisis de la primera sección del macrotexto: estrofas 1-3}

Estas tres primeras estrofas se configuran como el exordio de la plegaria compleja del macrotexto del poema, definido tradicionalmente como el comienzo del discurso cuyo objetivo es ganarse la simpatía del público hacia el asunto del discurso ${ }^{19}$, y marca

[...] el arranque de la secuencia dominante o envolvente que define al macrodiscurso como plegaria, al quedar perfectamente definida la presencia de un alocutario santo, la Virgen María, que se textualiza reiteradamente tanto mediante ocurrencias del pronombre personal de segunda persona singular bajo cualesquiera de sus casos, como mediante verbos o posesivos en la misma persona. ${ }^{20}$

En consecuencia, es conveniente abordar estas estrofas desde un análisis interno microtextual de índole retórica, dado que en tanto exordio es pasible de ser dividido en

295-296. Luego de clasificarlo como poema mariano doctrinal y simbólico; una primera, en la cual María ocupa el primer plano (estrofas 1-47); una segunda, referida a Cristo y su vida (estrofas. 48-196) y la tercera, dedicada a la alabanza de la Virgen (estrofas 197-233). El eje de su clasificación busca ser temático o de contenido: quién es el centro del relato (aunque aplicado de una manera llamativa, ya que circunscribe la vida de Cristo sólo a su momento público y no a su concepción, nacimiento e infancia (cc.20-41), y lo justifica apelando a cuestiones pragmático-gramaticales, ya que analiza el predominio de pronombres de segunda persona ( $\sin$ embargo, nótese que en la segunda parte no cesan tales pronombres alusivos a María ni las referencias). Esta estructuración, por lo tanto, no traduce de manera adecuada la articulación del texto ni su finalidad, mucho menos reconoce el acto de habla fundante, porque se centra exclusivamente en el contenido y, si se quiere, en lo cuantitativo. Lo divide únicamente por la res, pero sin integrarla en una macroestructura o estructura semántica global, y tampoco considera su forma o superestructura.

${ }^{19}$ LAUSBERG, Heinrich. Manual de retórica literaria. Fundamentos de una ciencia de la literatura. Madrid, Gredos, 1966, v. 1, p. 240.

${ }^{20}$ GONZÁLEZ, op. cit., p. 69. 
partes: la primera estrofa es una invocatio, los versos 2-3b, una narratio y $3 \mathrm{c}-4 \mathrm{~d}$, una petitio.

\section{A. Invocatio}

"A ti me encomiendo, Madre de pïadat, / que concebist' de Spíritu, e esto es verdat, / parist' fijo precioso en tu entegredat, / serviendo tu esposo con toda lealtat" (LNS, 1$)^{21}$.

El yo-laudatorio se encuentra definido por el verbo principal "encomiendo" en su uso pronominal, en primera persona del singular, que apela a un tú alocutario, caracterizado por un vocativo "Madre de pietat" y por dos proposiciones incluidas, dentro de las cuales María se constituye como sujeto gramatical. Se evidencia ya en esta primera estrofa la dinámica dialogal de la expresión del locutor que se manifiesta y afirma en relación a un tú (la alocutaria santa) a la vez interpelado e interpelante. Las características destacadas de María, reducidas a los semas principales, son su 'maternidad divina', su 'piedad', 'la virginidad' ('entegredat') y la 'lealtat'. A su vez, se pueden clasificar, en lo que concierne a su expresión gramatical, en características inherentes o cualidades (construcciones nominales como "Madre de pietat", "en tu entegredat") o en puntuales (indicadas por un verbo -"concebist", "parist"- o construcción gerundiva de valor adverbial), que consignan un acontecimiento singulativo de la economía de la salvación.

De esta manera, a partir de la aplicación de las macrorreglas propuestas por Van Dijk ${ }^{22}$ para la detección de la estructura interna de un texto, se puede sintetizar la invocatio en una estructura: "Tú / A ti, (que eres) X/ que hiciste Y, yo me encomiendo".

La plegaria es, por definición, un diálogo, entendido como un intercambio discursivo entre agentes que a través de la palabra interactúan y establecen una relación de ida y vuelta. Es asimétrico o un "metadiálogo", dada la diferencia ontológica absoluta entre el interlocutor hombre y el interlocutor Dios (o santo). Al poseer un interlocutor omnisciente e inmutable, se vuelve sumamente necesario considerar los actos de habla indirectos establecidos por la plegaria, dado que su interlocutor no puede ser informado

\footnotetext{
${ }^{21}$ En el presente trabajo todos los pasajes de la obra remiten a la edición crítica de Nicasio Salvador Miguel. Ver: Gonzalo de Berceo. Loores de Nuestra Señora. Edición y comentario de Nicasio Salvador Miguel. In: URÍA, Isabel (org.). Gonzalo de Berceo. Obra completa. Madrid: Espasa Calpe, 1992, p. 859-931. Todas las referencias a la obra se sintetizarán con la abreviatura LNS y subsiguientemente se indicará el número de estrofa.

${ }^{22}$ VAN DiJK, op. cit., p. 57-63.
} 
ni persuadido y, por lo tanto, las partes retóricas como la narratio y la argumentatio poseen una fuerza ilocutiva diferente de lo que la propia forma de los discursos significa. En consecuencia, se hace imprescindible descubrir en cada parte qué fuerza ilocutiva esconde. Al examinar las características de distintas plegarias de petición en obras de Berceo, González propone que las invocationes pueden ser entendidas retóricamente como argumentationes indirectas analógicas orientadas a la petitio, en otras palabras, argumenta para encarecer y defender la razón, necesidad o conveniencia de lo que pide ${ }^{23}$.

En el caso de esta invocatio de la primera estrofa, como acto de habla indirecto podría entenderse un giro pragmático en función de la petitio de los últimos dos versos del exordio (3cd): "A ti, porque eres X e hiciste $\mathrm{Y}$, yo me encomiendo". Constituiría entonces un locus proemial: un adiuncta personal, efectuado como descripción epidíctica de una persona, María, para engendrar su voluptas (aceptación de la encomienda) desde una captatio benevolentiae ${ }^{24}$ al mismo tiempo que se constituye como alabanza al afirmar sus cualidades y acciones como res certa (incluso subrayado por el modificador de la modalidad aseverativa "esto es verdat", pues especifica el grado de validez que el hablante otorga a lo afirmado anteriormente, sin necesidad de señalar una fuente originaria de lo que anuncia, dado su valor universal y ampliamente aceptado). En consecuencia, no puede afirmarse que exista una subordinación pragmática entre los elementos de alabanza y petición, sino una relación de interdependencia, por lo cual el efecto argumentativo es secundario y no la función principal.

\section{A. Narratio}

"En tu loor ${ }^{25}$, Señora, querría entender,/ de las tus largas faldas una fimbria tañer,/ ca non me siento digno ante ti parescer,/ maguer la tu feduça no la puedo perder.// En tu feduça, Madre, de ti quiero decir/ cómo vino el mundo Dios por ti redemir" (LNS, 2-3b)

Nuevamente desde el abordaje gramático textual, el yo-laudatorio indica la inminencia de su acción, que desarrollará en estrofas siguientes: "en tu loor [...] querría

\footnotetext{
${ }^{23}$ GONZÁLEZ, op. cit., p. 93.

${ }^{24}$ LAUSBERG, op. cit., vol. 1, p. 247, 254.

${ }^{25}$ Aquí no sólo se indica la intención del poeta, sino que también se emplea otro tópico característico del exordio, que es la dedicatoria o "consagración" (dicare, dedicare, consecrare, uouere), en este caso como ofrenda a María. Cfr. CURTIUs, Ernst Robert. Literatura europea y Edad Media latina. México: FCE, 1955, v. 1 , p. 133.
} 
entender" (2a) y "de ti quiero decir" (3a). En el segundo verso de la segunda estrofa, se acrecienta la captatio benevolentiae al remarcar su cualidad de indigno, un sutil ocultamiento de la eloquentia a través de una modestia auctoris ${ }^{26}$, tendente a captar la simpatía de la alocutaria al oponer su pequeñez a la confianza en la Virgen, cuyo auxilio solicita para "decir" sus loores. El acceso a María es a la vez intelectual y sensorial: por un lado, el entendimiento y, por el otro, los sentidos, representados por "tañer" hasta la manifestación verbal en el "decir", además de la efectividad de la imagen de $2 b$, que coloca al yo-laudatorio como un suplicante esperanzado en la eficacia del poder santo, como los enfermos de Mateo 9, 20-21 y 14, 36. En 3ab delimita la materia, el asunto a narrar, que es el loor a la Virgen por su rol en la economía de la salvación. Como indica Nicasio Salvador Miguel en las notas de su edición crítica del poema: "Cristo viene por María -gracias a María- a redimir el mundo"27, en consecuencia, se le otorga un papel de correndentora, por lo cual se narrarán los acontecimientos fundamentales de la historia de la salvación, vinculándolos a cada momento con la vida de la Madre de acuerdo con la tradición mariológica del siglo XIII, especialmente San Anselmo y San Bernardo.

La estructura básica de la narratio puede ser sintetizada, por lo tanto, de la siguiente manera: "Afirmaré (que eres) X/ (que hiciste) Y, (pero no me siento digno)".

\section{A. Petitio}

"Tú m' da bien empeçar, Tú m' da bien acomplir, / que pueda tu materia quál o cómo seguir" (LNS, 3cd)

En los estudios de retórica clásica, para la parte final del exordio, se suele sugerir un encajamiento con el comienzo de la narratio posterior pero también debe quedar claro que el exordio ha terminado y que comienza la narración ${ }^{28}$. Esta petitio funciona entonces como transitio, en tanto cierra el exordio al verbalizar la petición de auxilio, cuyos fundamentos ya han sido indirectamente expuestos anteriormente a través de la loa, como explica González: "la alabanza ínsita en la narratio, como también la que se incluye en la invocatio como captatio benevolentiae, podrían entenderse como indirectas

\footnotetext{
${ }^{26}$ LAUSBerG, op. cit., v. 1, p. 251; CURTIUS, op. cit., p. 128.

${ }^{27}$ Salvador Miguel, op. cit., p. 868.

${ }^{28}$ LAUSBERG, op. cit., v. 1 , p. 259.
} 
argumentaciones analógicas o ejemplares orientadas a la petitio" ${ }^{29}$. Sin embargo, la petición no es el fin último buscado: por el contrario, el poeta solicita ayuda para decir bien las cosas, en otras palabras, para alabar a María como corresponde a su condición. No hay un fin práctico que beneficie al locutor en esta petitio; por lo tanto, la petición y la alabanza se tornan interdependientes: no se puede postular una subordinación pragmática del elogio respecto a la petición ni viceversa, por lo cual se puede concluir que se trata de una plegaria mixta de alabanza y petición, sin subordinación definida en ninguna de ambas funciones a la otra. En consecuencia, la superestructura de la petitio sería: "Haz Z [para que yo logre afirmar (que eres) X/ (que hiciste) Y]".

Esta petitio introduce la parte que seguirá en el orden textual: los microtextos insertos de narratio-argumentatio, la afirmación del ser y de las acciones de María en el contexto de la historia de la salvación. Existe una relación anacrónica (en términos narratológicos) entre esta petitio microtextual y la narratio posterior: una referencia proléptica $^{30}$ intratextual que anticipa y desata lo que ha de relatarse y realizarse después textualmente, dado que el poeta consigue efectivamente cantar los loores.

En síntesis, en el exordio el poeta presenta la materia narrativa -'cómo vino el mundo Dios por ti redemir' (3b)- al mismo tiempo que indica su finalidad última: la alabanza a María -'en tu loor' (2a)-. A través de una serie de tópicos tradicionales, el locutor humano predispone la voluptas de la alocutaria para la primera petitio, concretada en $3 \mathrm{~cd}$, en la cual solicita su auxilio. El yo del locutor primero se ha sobredimensionado, al indicar sus necesidades y urgencias en la segunda estrofa, pero siempre en función de erigir como centro del discurso a María y su rol en la historia de la Salvación (estrofa 1 y 3), determinando la finalidad última de estas cuadernas y del poema entero: la alabanza. Al tratarse del exordio de la plegaria, lo trascedente se especifica como ascendente, en tanto un emisor humano o terreno asciende su discurso hacia un receptor divino o celestial: "Yo, hombre, digo a Dios/a María." En cuanto a la clase de plegaria, combina la petición y la alabanza. La superestructura reconocida para el exordio queda resumida del siguiente modo:

\footnotetext{
${ }^{29}$ GONZÁLEZ, op. cit., p. 69-70.

${ }^{30}$ La prolepsis es una anacronía - una discordancia entre el orden de la historia y del relato- que cuenta o evoca por adelantado un acontecimiento posterior. Ver GENETTE, Gérard. Discurso del relato. Ensayo de método. In: Figuras III. Barcelona: Lumen, 1989, p. 75-327. Especialmente p. 92, 95.
} 
Tú / A ti, (que eres) X/ que hiciste Y, yo me encomiendo. Invocatio

Afirmaré (que eres) X/ (que hiciste) Y, (pero no me siento digno) Narratio

Haz Z [para que yo logre afirmar (que eres) X/ (que hiciste) Y]". Petitio

\section{B. Análisis de la última sección del macrotexto: estrofas 195-233}

Al presentar su análisis estructural, García de la Concha designa esta última sección como "Loores y deprecaciones marianas" para luego subdividirla temáticamente en seis partes: "Función de María en el curso de la vida y en el día del juicio" (195-199), algunos ejemplos de su eficacia (200-203), Laus nominis (204-207), Apologética de su virginidad (208-214), María medianera de la Gracia (215-225) y Súplica final (226$233)^{31}$. En cambio, González define este apartado del poema como la conclusión de la plegaria emprendida en las tres estrofas iniciales ${ }^{32}$, categorización a la cual adherimos.

$\mathrm{Al}$ analizarlo desde un plano microtextual y retórico, se detecta la alternancia de distintas petitiones y narrationes, éstas últimas clasificadas en dos tipos predominantes: argumentaciones indirectas para fundar la petición que les sigue o alabanza de María mediante la mención de sus grandes hechos. Dada la extensión de esta sección, no se puede exponer en su totalidad el análisis textual, mas se han seleccionado pasajes significativos de su constitución para que puedan observarse sucintamente sus principales características.

\section{B. Estrofas 195 a 199: la función de María en el curso de la vida y en el día del juicio}

La narratio-argumentatio incrustada de las estrofas 4 a 194 concluye con la descripción del Juicio Final y sus consecuencias (estrofas 170-194), que el poeta exhorta a considerar en la vida terrenal y a obrar como corresponde para evitar un mal final (LNS, 193-194). Por lo tanto, la primera estrofa de la conclusio funciona como un transitio temática entre aquello y los elogios y las deprecaciones dirigidas a María: "En cabo, consiment' nos ave a prestar,/ ca nul nuestro buen fecho non nos podrié salvar;/ maguera, bien faciendo, nos conviene finar,/ ca la merced al fecho se quiere dirivar." (LNS, 195).

${ }^{31}$ García de la Concha, Victor. Los loores de Nuestra Sennora, un Compendium Historiae Salutis, Berceo, n. 94-95, 1978, p. 133-189. Especialmente p. 142.

${ }^{32}$ GonZÁlEZ, op. cit., p. 73. 
En este punto, como bien establece Menéndez Peláez ${ }^{33}$, el poeta dialoga con la mariología de San Bernardo de Claraval, dado que no se puede merecer la salvación a través de nuestras obras, pues nuestra naturaleza se encuentra corrompida, sino sólo a través de la Gracia y para eso debemos depositar nuestra confianza en María. Sin embargo, Berceo sugiere que, si bien nuestras obras no nos salvan, es conveniente que actuemos bien, pues así se busca su merced.

Si se examinan estos pasajes desde la semántica contextual, se constata un cambio en la voz del locutor, ya que no se corresponde gramaticalmente con una primera persona singular, sino que se establece el predominio de una primera persona plural, "nosotros", incoada en el microtexto previo de la narratio-argumentatio incrustada, que significa al género humano. En consecuencia, se comprueba la abundancia de las formas pronominales acordes, ya sea personales o posesivos, y los sufijos de la flexión verbal, en los cuales se reconoce un predominio de las formas presentes y futuras. Por otra parte, a partir de la estrofa 196, se retoma ${ }^{34}$ plenamente la apelación a María como alocutaria, aludida de nuevo con vocativos, formas pronominales de segunda persona singular y sufijos flexivos verbales. Su omnipresencia no es casual, ya que es el objeto del laus.

La estrofa 196 establece la base de la alabanza debida a María: "La mayor esperanza nos en Dios la tenemos,/ pero en ti, Señora, grant feduza avemos,/ ca tod' nuestro esfuerzo nos en ti lo ponemos" (LNS, 196abc). A partir de esta aseveración de fe, el poeta realiza el primer pedido: "¡Señora, Tú nos uvia,/ ante que periglemos!" (LNS, 196d). Desarrolla el poeta posteriormente los argumentos que avalan esta actitud de encomendarse a la Virgen, recurriendo a títulos tradicionales (LNS, 197-199), ejemplos (LNS, 200-203), nombres (LNS, 204-207) y una apología de su virginidad (LNS, 208213).

\section{B. Estrofas 215-255: María medianera de Gracia}

En esta sección se retoma la alternancia entre narrationes y petitiones con la que se había iniciado la conclusio. De este mismo modo, se refuerza la presencia de la primera

\footnotetext{
${ }^{33}$ MENÉNDEZ PELÁEZ, op. cit., p. 118-119.

${ }^{34}$ No se quiere significar con esto que se haya abandonado a María como alocutaria en la narratio previa, sino que su presencia no es tan abundante ni reiterativa en algunos de estos microtextos como sí sucede en el exordio y la conclusión.
} 
persona plural, ya sea como sujeto de los demandas o como beneficiario de la acción favorable de la alocutaria. Se recapitula uno de los ejes de la narratio-argumentatio de las estrofas 4-194, la restauración obrada por María: "La paz e la salut por ti fue reformada,/ toda la vieja saña por ti fue perdonada" (LNS, 215ab). Esto se halla amplificado: "Por ti salió el pueblo de la premia mortal,/ por ti fue restaurada la mengua celestial" (LNS, 216ab). Se afirma con intención plenamente laudatoria su condición de reina: "reales son tus cosas e Tú mesma real,/ onde diz' el escripto que non ovist' egual" (LNS, 216cd) y su disposición ante las plegarias en su carácter de omnipotentia supplex: "a ti corre la lengua, quando cuita avemos;/ Tú ante estás presta, que nos te demendemos,/ muchas veces cadríemos que por ti non caemos" (LNS, 217abc).

Otro recurso son las parejas inclusivas (extremos que incluyen todos los puntos intermedios), para describir a los devotos de María: "Varones e mugieres por Madre te catamos/ [...] peccadores e justos tu merced esperamos" (LNS, 218ac), "'Ángeles e archangeles, tronos e senïores,/ apóstolos e mártires,/ justos e confessores,/ con stolas e manípulos cantan a ti loores" (LNS, 219abc). Esta enumeración de fieles concluye en la estrofa 220: "A ti siguen las vírgenes, como a su madrona,/ glorifican e laudan todas la tu persona" (LNS, 220ab).

Las tres breves petitiones intercaladas solicitan el auxilio de la Virgen, especialmente en el Fin de los Tiempos, pero también en la vida terrenal: "acórrinos, Señora, sëy nuestra pagada,/ca yaz' en grant peligro la nuestra cabalgada" (LNS, 216cd), "Tú nos guía, Señora, com' tus fijos seamos;/ peccadores e justos tu merced esperamos,/ fernos á Dios la suya por ti, como fiamos" (LNS, 218bcd), "Reína coronada de tan noble corona,/ te femos abogada, lo nuestro Tú razona". Por el contrario, en las estrofas 221 a 223 se desarrolla una petitio extensa; primero, se recapitula el carácter indigno del poeta para cantar los loores, como en el exordio: "Razón faz' e derecho que te pueda laudar,/ mas nos con grant peccado non lo podemos far" (LNS, 221ab), por lo cual implora la intervención de María en búsqueda de una óptima loa: "emperadriz gloriosa, deña a nos catar,/ que podamos tu gloria dignamente cantar" (LNS, 221cd). Luego, solicita el auxilio contra el Mal, para los tres combates (la carne, el mundo y el demonio): "E síguennos, Señora, grandes enemistades,/ contra nos es el mundo con sus adversidades,/ ayúdale el dïablo con muchas falsedades,/ con ellos tien' la carne con falsas voluntades" (LNS, 222). 
Finaliza con una pregunta retórica, que subraya la indefensión humana ante tales enemigos: "Entre tantos peligros, ¿qui podrié guarecer?" (LNS, 223a) y la solicitud de auxilio: "Si nos non vales, Madre, podemos nos perder;/ reina de los cielos, piénses' nos d' acorrer,/ en prunada nos tienen, cuidánse nos vender" (LNS, 223bcd).

Vuelve a ensalzar a María en la última narratio-argumentatio del poema, nuevamente acudiendo al tópico de la indecibilitas (combinado con una fórmula de abbreviatio) por la cantidad: "Non podrié fuerza d' omne fablar e comedir/ de quánt grandes donaires te quiso Dios vestir" (LNS, 224ab) y en la hipérbole del número, comparándolo con la inconmensurabilidad del mar: "Tal es la tu materia, Señora, com' el mar,/ todos tus dezidores an ý que empezar;/ si deviesse el mundo cient mil años durar,/ non podrién lenguas d' omnes el diezmo acabar" (LNS, 225).

\title{
3. B. Estrofas 226-233: Súplica final
}

Comienza la última sección del poeta con un pedido general para toda la Iglesia: "Señora e reína de tal auctoridat,/ de los tus peccadores préndate pïadat,/ da tu misericordia sobre la christiandat" (LNS, 226abc). Especifica el ruego a lo largo de las estrofas 227 a 229, construyendo mediante bimembración pares de suplicantesbeneficiarios, en general por pareja inclusiva: "Acorri a los vivos, ruega por los passados,/ [...] conserva los pacíficos, reforma los irados" (LNS, 227ad), "alivia los andantes, levanta los jacientes,/ sostién' a los estantes, despierta los dormientes" (LNS, 229bc).

En las estrofas 230 a 232 se retoma el yo-laudatorio en singular como instancia de apelación personal del poeta a la Virgen, como así también portavoz y representante del género humano, por el cual pide y ruega:

\begin{abstract}
Madre, merced te pido por mis atenedores;/ ruégot' por mis amigos, que siempre los mejores;/ rescivi en comienda parientes e señores;/ en ti nos encargamos todos los peccadores.// Por mí, que sobre todos pequé, merced te pido;/ torna sobre mí, Madre, non m' eches en olvido,/ träíme del peccado, do yago embevido,/ preso só en Egipto, los vicios m' an vendido.// Aún merced te pido: por el tu trobador ${ }^{35}, /$ qui est' romance fizo, fue tu entendedor,/ seas contra tu fijo por elli rogador,/ recábdali limosna en casa del Crïador. // Ruega por la paz, Madre, e por el temporal,/ acábdanos salud e cúrianos de mal,/ guíanos en tal guisa por la vida mortal,/ com' en cabo ayamos el regno celestial." (LNS, 230-233).
\end{abstract}

\footnotetext{
${ }^{35}$ Se reitera el empleo de términos cortés-trovadorescos para designar al poeta, en este caso, "trobador" (que no debe entenderse como argumento definidor de la naturaleza creadora, sino como artificio literario) y "entendedor", resemantizado como "devoto".
} 
La Virgen es invocada como "Madre" (230a, 231b, 233a) desde un yo-suplicante en el primer verso de cada estrofa: 'te pido' (230a, 231a, 232a), primero para solicitar misericordia para su público y contemporáneos en la estrofa 230; luego, para sí mismo en las estrofas 231-232, con una breve instancia de confesión de pecados y arrepentimiento $(230 \mathrm{acd})^{36}$ y un requerimiento desde su condición de poeta, cantante de loas (232ab) para que interceda como abogada ante Cristo juez por él (232cd) y por toda la humanidad (en la estrofa 233). En tanto petitio, esta plegaria supone una referencia a hechos futuros, una prolepsis en términos de anacronía narratológica, cuya verificación se implora y espera. Pero tal verificación en Loores no puede realizarse textualmente, dado que alude a dimensiones extratextuales (nuestra salvación).

En síntesis, el poeta claramente se dirige en este final del discurso religioso a la alocutaria desde una posición asimétrica ascendente de suplicante (luego de haberla alabado debidamente a lo largo de las distintas narrationes y petitiones de las estrofas previas, 195 a 229) para mover sus sentimientos a la compasión, típica función de la conclusión. Potencialmente, en lo que respecta a los efectos perlocutivos ${ }^{37}$, también puede funcionar como un acto de habla indirecto hacia los hombres, para que alaben a María, dado que la res certa ha sido reafirmada o enfatizada debidamente a lo largo del poema: ella es realmente nuestra abogada intercesora, es poderosa y misericordiosa, y por ello, laudable y servible.

La primera persona plural no funciona como alocutario (como sucede en algunas instancias de la narratio-argumentatio incrustada), sino como emisor en cuanto se concretiza un desplazamiento de la voz narrativa del locutor. A diferencia de la secuencia narrativa incrustada, no se procura involucrar al interlocutor con el relato de los hechos de la Salvación, sino más bien proponerlo como beneficiario y suplicante ante la Virgen María. De este modo, el poeta se constituye plenamente como portavoz de la humanidad,

\footnotetext{
${ }^{36}$ Es el tercer momento de un discurso personal del locutor de índole confesional y de arrepentimiento. Los dos anteriores se encuentran en el microtexto de narratio-argumentatio: en la Meditación ante la Cruz (9495) y en la contemplación escatológica (176-181), estudiados en otros artículos en prensa.

${ }^{37}$ En una aclaración similar, pero respecto a la discutida ejemplaridad de los milagros marianos, González explica: "Es precisamente en los efectos perlocutivos, la dimensión que escapa a las intenciones del emisor y que se infiere a partir de los reales y concretos efectos que ha logrado producir en los receptores, [...] donde puede radicar cierta cuota, siempre limitada y aleatoria, de ejemplaridad didáctica, lo cierto es que la alabanza en que consiste el discurso puede resultar en algún caso "contagiosa" para algún individual receptor y puede ser tenida por imitable, por lo cual deviene secundaria y ocasionalmente en ejemplar" (GONZALEZ, op. cit., p. 157).
} 
integrada coralmente como sujeto colectivo de la acción de alabar y pedir. Este "nosotros" colectivo se afirma entonces mediante su explícita sumisión y subordinación al tú divino, y en esta kénosis es donde encuentra el sujeto su más firme fundamento identitario, especialmente en aquellos versos plenamente latréuticos. Estos enunciados son claramente asertivos: testifican la fe de la cristiandad en la intercesión de María. La enumeración de los nombres y ejemplos marianos, además de la explicación de su función simbólica, culmina siempre con la aplicación a nuestro favor, que ilustra la motivación de la "feduça" puesta en María. Todas estas narrationes, en consecuencia, son una clase de énfasis que la retórica tradicional ha denominado ratiocinatio y que consiste en la mención detallada de las circunstancias que acompañan al objeto postulado como elogiable $^{38}$. De este modo, desde un abordaje pragmático, se puede concluir que las narrationes, ya sea laudationes o argumentationes, son recapituladas en estos apelativos de una manera concentrada con la intención de influir en los afectos, de tal manera que se oriente al público en sentido favorable a la causa ${ }^{39}$, en este caso, a María, para que ruegue por nosotros, $\mathrm{y}$, potencialmente en lo que respecta a los efectos perlocutivos, a los hombres, para que alaben a María, dado que la res certa ha sido enfatizada adecuadamente.

Por otro lado, los enunciados impetratorios se caracterizan por un locutor suplicante cuyo objetivo primordial es la intercesión mariana para obtener la misericordia de Dios. No obstante, también existen petitiones orientadas puramente a la laus (como en el exordio), en otras palabras, cuyo beneficiario no es la humanidad, sino la misma María, como objeto del laus, por ejemplo en $221 \mathrm{~cd}^{40}$.

Por lo tanto, podemos sintetizar la superestructura de la conclusio:

(Porque) Tú, eres X/hiciste Y Narrationes (laudationes o argumentationes)

Haz Z Petitiones

\footnotetext{
${ }^{38}$ LAUSBERG, op. cit., vol. 1, p. 343.

${ }^{39}$ LAUSBERG, op. cit., vol. 1, p. 361; 364.

40 "Emperadriz gloriosa, deña a nos catar,/ que podamos tu gloria dignamente cantar" $(221 \mathrm{~cd})$
} 


\section{Loores como plegaria de alabanza y petición: los actos de habla principales del macrotexto}

A lo largo de todo el macrotexto la textualización de lo trascendente se ha realizado mediante el rol del alocutario, en segunda persona, desde un yo-locutor (en el exordio) que es a la vez laudatorio y suplicante. En la conclusión, esta voz se colectiviza para involucrar al género humano, como consecuencia de los hechos salvíficos relatados en la narratio-argumentatio incrustada, que demandan una respuesta por parte de la cristiandad. El nosotros-locutor se propone entonces como beneficiario de la intercesión mariana y cantante de sus loas, una respuesta positiva ante la interpelación divina, con la esperanza de poder participar del reino celestial. Al finalizar el poema se retorna al locutor en primera persona singular, con una gran fuerza expresiva de índole patética, para predisponer a María a su favor.

Esta textualización de la Virgen María como alocutaria ubica a Loores de Nuestra Señora como plegaria dentro de los discursos religiosos. Para identificar su subclase, ha sido preciso un detallado análisis retórico y formal del exordio y la conclusión con el objetivo de determinar la superestructura del macrotexto del poema:

Tú / A ti, (que eres) X/ que hiciste Y, yo me encomiendo.

Afirmaré (que eres) X/ (que hiciste) $\mathrm{Y}$, (pero no me siento digno)

Haz Z [para que yo logre afirmar (que eres) X/ (que hiciste) Y]".
Invocatio

Narratio

Petitio

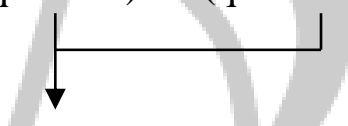

Narratio-argumentatio

[Microtexto de la historia de la Salvación compendiada en María]

(Porque) Tú, eres X/hiciste Y

Haz Z
Narrationes (laudationes o argumentationes)

Petitiones 
A lo largo de la exposición, se ha podido determinar que las narrationes no suelen hallarse subordinadas a las petititiones como argumentatitiones para encarecer y defender la conveniencia de lo que se pide, sino que mayoritariamente se edifican principalmente como laudationes, en enunciados tú-valorativos, que no se funden directamente con la petición. En consecuencia, existe una relativa independencia y plena igualdad jerárquica de invocatio, narratio y petitio propia de la plegaria mixta de alabanza y petición.

Se deben examinar ahora los actos de habla fundantes de dichos tipos textuales, según lo expuesto en el primer apartado y las características de su género retórico. En tanto alabanza, el acto de habla corresponde a una aserción-laudatoria, dado que aquello que se afirma como res certa constituye en sí una alabanza, cuyo objeto es María. En lo que concierne a la petición, consiste en una exhortación o enunciado directivo, ya que se intenta inducir a María a que ejecute una acción determinada: la intervención por nosotros, por nuestra salvación, que es una res dubia de carácter futuro.

\section{A. Enunciado asertivo-laudatorio: laus}

En tanto laus, Loores pertenece al género aristotélico denominado demonstrativum o epidíctico, ya que es un tipo de discurso cuyo propósito es elogiar (en tanto res honesta) a una persona para proclamar o ratificar una realidad evidente o aceptada, una res certa ${ }^{41}$, acerca de la cual el destinatario asume una actitud pasiva, limitada a asentir y a gozar. Dentro de los distintos elogios posibles ${ }^{42}$, esta plegaria corresponde al tipo de encomio encuadrable en el laudantur vel vituperantur homines, dado que María es humana, no divina. En cuanto a su subclasificación, es problemática, dado que alude tanto a ex tempore quod ante eos fuit (hechos anteriores a su vida terrenal: los signos y profecías del Antiguo Testamento, por ejemplo, que son su prolepsis en el microtexto: ex auguriis), ex tempore quo ipsi vixerunt (hechos que vivió: todo lo referido al Nuevo Testamento, en particular su rol en la Vida de Cristo) y ex tempore quod est insecutum (hechos posteriores a su vida terrena: sus intercesiones y milagros, por

\footnotetext{
${ }^{41}$ LAUSBERG, op. cit., vol. 1, 109-110; 213-214.

${ }^{42}$ LAUSBERG, op. cit., vol. 1, 217-219.
} 
ejemplo, de Teófilo y María Egipciaca). En este sentido, se constata el carácter pancrónico de toda alabanza, según lo que apunta González al analizar las anacronías ${ }^{43}$ :

la plegaria de alabanza se revela como esencialmente ucrónica, o mejor, pancrónica, pues en la narratio central en la que radica la alabanza no se alude a ninguna instancia temporal perfectiva ni futurible, sino al eterno presente de Dios o bien al durativo presente de los santos alocutarios; se trata de una narratio que alude a circunstancias del extratexto, como los grandes hechos de la historia sagrada por los cuales se alaba a Dios o a los santos. $^{44}$

Los microtextos insertos deben ser entendidos con el objeto de ratificar o reforzar el elogio, como un caso de amplificatio, fenómeno propio de la ornatus. Se trata de aumentar la fuerza de una idea indudable y ya aceptada (el poder, la misericordia y la laudabilidad de María) mediante la acumulación tanto de res (los hechos que dan cuenta de su poder, misericordia y laudabilidad a lo largo de la historia de la salvación) como de verba (la organización discursiva de esos hechos mediante técnicas narrativas y retóricas).

Agrega González que en la laus el sentido del texto radica en forma completa y perfecta dentro del mismo texto, pues la fuerza ilocutiva básica asertivo-laudatoria que lo define como acto de habla se realiza acabadamente en y por el propio discurso: "El texto mismo es de suyo una acción [...] por lo que se nos presenta de este modo como un enunciado performativo, como un tipo de acto verbal en el que coinciden el decir y el hacer"45. Decir que María es loable es loarla; narrar a la Virgen en su poder y piedad, equivale a rendirle culto de devoción y alabanza. Aunque pueda contemplarse la eventualidad de un efecto perlocutivo de cierta emulación del acto devocional por parte de algún receptor, este efecto no resulta necesario para que el texto advenga a su sentido pleno ni agrega nada sustancialmente nuevo: se limita a duplicar o reforzar coralmente la misma y única alabanza de la plegaria.

Tampoco se trata de probar o demostrar la licitud o conveniencia de una conducta, no se trata de proponer conducta alguna como emulable o evitable: María, no resulta en absoluto imitable a causa de su excelsitud incomparable. Por lo tanto, Loores de Nuestra

\footnotetext{
43 Definidas por Gérard GENETTE (op. cit., p. 92-95), las anacronías son las diferentes formas de discordancia entre el orden temporal de la historia y del relato. Existen dos tipos básicos: la prolepsis (toda maniobra narrativa que consista en contar o evocar por adelantado un acontecimiento posterior) o la analepsis (toda evocación posterior de un acontecimiento anterior al punto de la historia).

${ }^{44}$ GONZÁlEZ, op. cit., p. 236.

45 GonZÁleZ, Javier Roberto. Los Milagros de Berceo: alegoría, alabanza, cosmos. Buenos Aires: Miño y Dávila Editores, 2013. Especialmente p. 168.
} 
Señora no puede clasificarse como exemplum, dentro del genus deliberativum ${ }^{46}$. Además, la res propia del exemplum es la dubia, dado que se caracteriza por su declarado propósito de enseñar moral y talante didáctico que persigue como fin exhortar o inducir a una determinada conducta práctica conforme al sistema de valores vigente a partir de la demostración de la conveniencia o inconveniencia de adoptar para el futuro determinada medida cuya índole se presenta como incierta o dudosa ${ }^{47}$. En ningún momento del macrotexto Berceo duda sobre las cualidades de María ni sobre su rol en la historia de la Salvación. Por el contrario, se trata como una res certa, que se enfatiza a través del argumento narrativo como un argumentum ab exemplo que ilustra en concreto la laudabilidad de María.

\section{B. Enunciado exhortativo-directivo o impetratorio: suadere}

En lo que respecta a su segunda naturaleza, la petición, se la puede clasificar dentro de la modalidad volitiva-exhortativa, que corresponde al género aristotélico del deliberativum, en otras palabras, un discurso pronunciado para deliberar y tomar una decisión respecto a una acción futura que el orador, en este caso, aconseja como útil o buena, por lo tanto, suadere ${ }^{48}$. El poeta desea y le pide a María que nos guíe en nuestra vida mortal e intervenga por nosotros en el Juicio Final, lo cual supone una res dubia futura. Por lo tanto, si en la alabanza narratológicamente se reconoce esencialmente un tiempo narrativo de índole pancrónica, en la petición, en tanto enunciado exhortativo, se identifica una tensión proléptica, porque supone una necesaria referencia a hechos futuros.

Si bien el momento temporal al que se refiere el asunto del genus es el futuro, para su mayor conocimiento pueden también tratarse asuntos del pasado y del presente, que son los exempla. Los exempla son un caso particular por su contenido, limitado a la res gestae, en este caso de fuente histórica, de la similitudo general, que pone en relación

\footnotetext{
${ }^{46}$ A favor de la tesis didáctica-ejemplar, cfr. GARCÍA DE LA CONCHA, op. cit, p. 144; GARCíA DE LA ConCHA, Víctor. La mariología de Gonzalo de Berceo. In: Gonzalo de Berceo. Obra completa. Madrid: Espasa Calpe, 1992, p. 61-87. Especialmente p. 63-65; MenÉNDEZ PelÁEZ op. cit., p. 113; URIARTE ReBAudi, Lía. Poesía mariana en Gonzalo de Berceo, Letras. Studia Hispanica Medievalia V, n. 40-41, 1999-2000, p. 7-12, especialmente p. 11.

${ }^{47}$ LAUSBERG, op. cit., v. 1, p. 203-205, 347-358.

${ }^{48}$ LAUSBERG, op. cit., v. 1, p. 109.
} 
comparativa con la causa, con fines de hacerlo creíble, todo fenómeno semejante ${ }^{49}$. En este sentido deben entenderse análogamente los microtextos de narrationesargumentationes que preceden a la petición en Loores, ya que, además de narrar (y en tanto acto de habla, el decir supone la alabanza) la historia de la salvación en función de María, se apela a ella para que siga obrando de la misma manera con el resto de la cristiandad, a pesar de nuestra condición de pecadores.

La argumentación narrativa tiene una fuerza ilocutiva de "fundar un pedido", en tanto desempeña la función de argumentar ante María las razones por las cuales puede y debe conceder al hablante lo que pide; el argumento se define como un argumentum a pari, que presenta mediante frases asertivas una serie de hechos del santo implorado que evidencian su poder o misericordia, su capacidad de realizar actos similares.

\section{CONCLUSIONES}

Loores de Nuestra Señora es un discurso religioso de tipo plegaria en su nivel macrodiscursivo, ya que lo trascendente-santo se textualiza como alocutario, en segunda persona (la Virgen María). El macrotexto abarca el exordio de las estrofas iniciales (1-3) y la conclusio de las finales (195-233), a las cuales se subordina como narratioargumentatio la extensa secuencia de componentes heterogéneos (mayoritariamente narrativos, pero también doctrinales y expresivos) de las estrofas 4-194.

En cuanto a su clasificación dentro de las plegarias, el macrotexto de Loores se configura como mixto de dos actos de habla básicos independientes, la alabanza y la petición. La materia y objeto de tal laus y petición son justamente la misma Virgen y su rol instrumental (especialmente de corredentora) en la historia de la salvación según la devoción mariana de hiperdulía de la época. Esa narración de hechos salvíficos funciona como microdiscurso de narratio-argumentatio: tanto exposición ratificadora a favor del elogio debido a la Virgen como fundamento de la petición.

Se han analizado los componentes textuales presentes en relación con los rasgos propios del genus que deriva de ambos actos de habla, conforme a lo establecido por la retórica. Mientras que los enunciados laudatorios corresponden al género demonstrativum, en tanto res certa honesta reafirmada, los enunciados exhortativos se

\footnotetext{
${ }^{49}$ LAUSBERG, op. cit., v. 1, p. 355.
}

$$
141
$$


inscriben más bien en el deliberativum, por tratarse de una res dubia de carácter futuro, que intenta persuadir a María para que continúe interviniendo en nuestro favor a pesar de los pecados. Se ha propuesto también una caracterización narratológica de ambos genera y sus actos de habla correspondientes a partir de la categoría de la anacronía. Se verificó así la tensión proléptica basal de la petición y la naturaleza pancrónica de la plegaria.

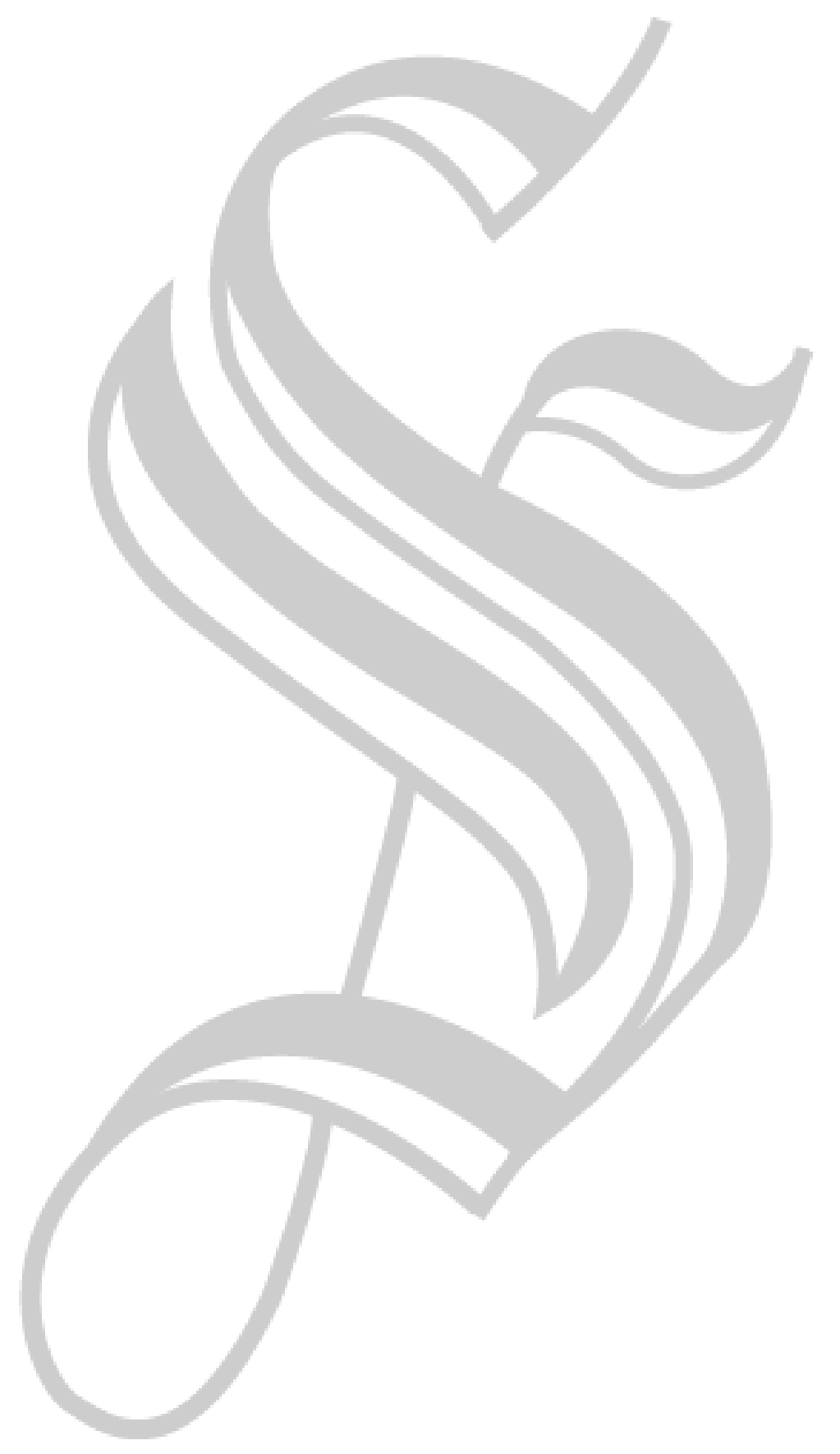

